\title{
KRITIK SOSIAL DALAM NOVEL MAAFKAN AKU, KUALA MESUJI \\ KARYA FAJAR: TINJAUAN SOSIOLOGI SASTRA
}

\section{SOCIAL CRITICISM IN THE NOVEL MAAFKAN AKU, KUALA MESUJI WORKST FAJAR: SOCIOLOGY LITERATURE REVIEW}

\author{
Erwin Wibowo \\ Kantor Bahasa Lampung \\ Jalan Beringin II No. 40 Kompleks Gubernuran, Telukbetung, Bandarlampung \\ Ponsel: 085269940405; Pos-el: erwin.wibowo@ymail.com
}

\begin{abstract}
Abstrak
Penelitian terhadap novel Maafkan Aku, Kuala Mesuji ini bertujuan untuk mengungkap kritik sosial yang terkandung dalam novel Maafkan Aku, Kuala Mesuji karya Fajar melalui pendekatan sosiologi sastra. Metode yang digunakan dalam penelitian ini adalah metode deskriptif kualitatif, dengan teknis analisis isi yaitu mengungkap dan kemudian mendeskripsikan unsur ekstrinsiknya, apa dan bagaimana kritik sosial yang dikandung dalam novel tersebut. Fokus penelitian ini adalah kritik sosial yang terkandung dalam novel Maafkan Aku, Kuala Mesuji karya Fajar yang meliputi: pertama, kritik sosial terhadap kehidupan masyarakat Kuala Mesuji. Kedua, kritik sosial terhadap pendidikan yang ada di Kuala Mesuji. Tehnik analisis yang dilakukan peneliti yaitu membaca dan memahami isi novel, menganalisis kritik sosial, kemudian menginterpretasikan data sesuai dengan indikator fokus penelitian dan fakta (peristiwa) yang melatarbelakangi kritik sosial yang ditemukan. Berdasarkan hasil penelitian menunjukan bahwa dalam novel Maafkan Aku, Kuala Mesuji karya Fajar, mengandung kritik sosial yang dimunculkan dari percakapan para tokoh dan juga melalui narasinya.
\end{abstract}

Kata kunci: novel, sosiologi sastra, kritik sosial

\begin{abstract}
Research on novel Maafkan Aku, Kuala Mesuji aims to uncover the social criticism contained in the novel Maafkan Aku, Kuala Mesuji Dawn works through literature sociological approach. The method used in this research is descriptive qualitative method, with which the technical content analysis to uncover and then describe the extrinsic elements, what and how social criticism contained in the novel. The focus of this research is social criticism contained in the novel Maafkan Aku, Kuala Mesuji Dawn works which include: first, social criticism on people's lives Kuala Mesuji. Second, the social criticism of the education in Kuala Mesuji. Engineering analysis conducted by researchers are read and understand the contents of the novel, to analyze social criticism, and then interpret the data according to the indicators focus on research and facts (events) underlying social criticism found. Based on the research results show that the novel Maafkan Aku, Kuala Mesuji works of Dawn, does contain social criticism that is raised from the conversation the leaders and also through the narrative.
\end{abstract}

Keywords: novel, sociology of literature, social criticism

\section{Pendahuluan}

Sastra sebagai sebuah teks tidak dapat melepaskan diri dari peran pengarang dan lingkungan terciptanya karya sastra tersebut. Sebagaimana semua hasil sastra, sastra
Indonesia modern tidaklah lahir dari situasi kekosongan budaya (Teeuw, 1983: 11). Hal ini berarti bahwa antara sastra, pengarang, dan lingkungan merupakan hal yang sangat berkaitan karena karya sastra tidak lepas dari 
budaya yang diangkatnya dan budaya adalah bagian dari kehidupan sosial sehingga karya sastra dapat dipandang sebagai gambaran sosial masyarakat pada waktu tertentu yang berhubungan dengan masalah-masalah sosial.

Salah satu media yang paling ampuh untuk menyuarakan kritik sosial adalah karya sastra. Melalui karya sastra, kritik sosial yang disuguhkan merupakan kritik terhadap segala bentuk keadaan, tindakan sosial individu maupun masyarakat yang dirasakan menyimpang dari norma atau nilai sosial yang berlaku di dalam masyarakat, yang dituangkan ke dalam karya sastra dengan tujuan menciptakan kehidupan yang lebih baik.

Salah satu fungsi karya sastra adalah sebagai hiburan. Selain sebagai hiburan, karya sastra juga merupakan media bagi sastrawan untuk mencurahkan segala apa yang dirasa atau dilihat pada kurun waktu tertentu. Disebutkan pula bahwa salah satu peran sastra adalah sarana atau alat untuk mengomunikasikan gagasan, pikiran, perasaan, pandangan, dan tanggapan mengenai segala sesuatu yang terjadi (Kuntowijoyo, 1987: 32).

Menurut Soekanto (2005: 314), masalahmasalah sosial timbul karena adanya hubungan yang tidak harmonis antara masyarakat dan lembaga-lembagakemasyarakatan di dalamnya sehingga menyebabkan kesulitan-kesulitan dalam bersosialisasi dan menyesuaikan diri dengan berbagai macam hubungan sosial. Masalah-masalah sosial tersebut oleh sebagian seniman yang juga merupakan anggota masyarakat tidaklah dihindari atau disia-siakan begitu saja termasuk oleh pengarang. Pengarang yang produktif, cerdas, dan peka terhadap realita sosial, akan mampu mengolahnya dalam karya sastra sebagai cerminan kondisi sosial budaya masyarakat dengan mengemban tujuan tidak hanya bersifat menghibur saja, akan tetapi juga mendidik, mengkritik, dan memperbaiki keadaan melalui persuasif yang tertuang dalam karya-karyanya.

Kritik sosial muncul karena adanya konflik sosial. Dengan adanya konflik sosial masyarakat menyuarakan pendapat, tanggapan, dan celaan terhadap hasil tindakan individu atau kelompok masyarakat. Kritik sosial bisa disampaikan baik secara langsung maupun tidak langsung. Secara tidak langsung, kritik sosial dapat disampaikan melalui media. Media penyampaian kritik sosial beraneka ragam jenisnya.

Kritik sosial yang ada di dalam karya sastra dapat berupa kritik terhadap kehidupan sosial yang ada dalam kehidupan nyata, yaitu berupa ketimpangan sosial yang sering menimbulkan masalah-masalah sosial. Sastrawan atau pengarang dalam karya yang diciptakannya mampu menggambarkan realita kehidupan sosial melalui tokoh-tokoh di dalamnya. Tokoh-tokoh yang diciptakan tersebut berperan sebagai simbol-simbol seperti keserakahan, nafsu, dendam, dan kejahatan lainnya yang menyebabkan masalahmasalah sosial.

Menurut Darma (1995: 136) kritik sosial merupakan salah satu ciri karya sastra. Karya sastra yang baik juga diwarnai oleh kritik sosial sedangkan menurut Arnold (Ibid: 136) disebutkan bahwa sastra adalah "criticism of life" kritik hidup memang lebih luas daripada kritik sosial, akan tetapi titik tolaknya sama, yaitu kritik. Berdasarkan pernyataan di atasmaka dapat dikatakan bahwa setiap karya sastra yang baik adalah karya yang mengandung unsur kritik di dalamnya, baik kritik hidup maupun kritik sosial. Hal ini disebabkan kritik itu sendiri merupakan ciri atau bagian dari karya sastra, yaitu mengenai ungkapan dan sikap hidup pengarangnya terhadap realita yang ada.

Kritik sosial yang ada di dalam karya sastra dapat berupa kritik terhadap kehidupan sosial yang ada dalam kehidupan nyata, yaitu berupa ketimpangan sosial yang sering menimbulkan masalah-masalah sosial. Sastrawan atau pengarang dalam karya yang diciptakannya mampu menggambarkan realita kehidupan sosial melalui tokoh-tokoh di dalamnya. Tokoh-tokoh yang diciptakan tersebut berperan sebagai simbol-simbol seperti keserakahan, nafsu, dendam, dan kejahatan lainnya yang menyebabkan masalahmasalah sosial.

Dewasa ini banyak sastrawan yang memilih tema masalah sosial dalam karya sastranya. Hal ini dilakukan sebagai wujud 
kritik sosial terhadap pemerintah, pemimpin, dan realitas sosial yang dipandang tidak memihak dan mementingkan masyarakat. Sastrawan menyuarakan kritik sosial terhadap realitas yang terjadi. Ia menjadi juru bicara masyarakat. Ia mengemukakan keluhan dan harapan masyarakat. Hal ini terkait dengan realitas sosial yang tidak sesuai dengan harapan manusia. Ketidaksesuaian realitas dengan harapan cenderung menimbulkan ketidakpuasan dan rasa ketidakpuasan tersebut memunculkan kritik sosial yang dikemukakan melalui berbagai media. Sastra merupakan salah satu media untuk menyampaikan kritik sosial. Apabila karya sastra digunakan sebagai media untuk menyampaikan kritik terhadap realitas sosial yang tidak berpihak kepada kepentingan masyarakat, maka karya sastra sesungguhnya sedang melakukan perannya sebagai kontrol sosial.

Salah satu novel yang berisikan tentang kritik sosial adalah novel Maafkan Aku, Kuala Novel. Novel ini bercerita tentang potret buram anak-anak di Kuala Mesuji, suatu daerah yang ada di Mesuji, Lampung. Potret buram tentang pendidikan, tentang kehidupan anak-anak yang jauh dari kata layak, hingga menyebabkan munculnya problem sosial di Kuala Mesuji. Pemekaran wilyah yang terjadi beberapa waktu lalu belum memberikan dampak positif bagi kehidupan masyarakat di Kuala Mesuji.

Novel ini dibuka dengan cerita tentang perjuangan seorang wanita bernama Lin. Lin seorang wanita yang tak tahu lagi bagaimana cara menghidupi keluarganya, hingga akhirnya Lin masuk ke lembah prostitusi. Lin seorang ibu dari seorang anak yang bernama Sisca, yang sejak kecil diasuh oleh neneknya. Awal mulanya Lin menjadi seorang pelacur di lokalisasi Gang Doly, Kota Surabaya. Setelah lokalisasi tersebut ditutup, Lin hijrah ke Mesuji, di Mesuji Lin tetap masih menjadi seorang pelacur. Akan tetapi hati kecil Lin, sangat ingin dia menyudahi pekerjaan yang hina ini, hingga pada suatu hari Lin memutuskan untuk berhenti menjadi pelacur, dan berniat kembali ke Solo untuk bertemu dengan suami dan anaknya. Tekad yang kuat menghantarkan Lin untuk menyudahi pekerjannya ini.

Hingga pada suatu hari Lin meninggalkan Mesuji, untuk kembali ke Solo. Dalam perjalanan ke dermaga, angkutan umum yang membawa Lin dan beberapa penumpang di berhentikan oleh kawanan perampok yang ingin merampas semua barang bawaan penumpang termasuk Lin. Lin yang saat itu melawan para begal, mengalami nasib yang sangat teragis, dalam keadaan tak berdaya, Lin ditenggelamkan di Sungai Mesuji

Lin masih disayang Tuhan, tubuh Lin ditemukan oleh seorang pemuda dan dibawa ke rumahnya. Hingga pada akhirnya Lin tersadar sudah berada di rumah pemuda tersebut. Jebat adalah mana pemuda itu, anak semata wayang dari Mak Romlah. Jebat berprofesi menjadi seorang nelayan di muara yang dekat tempat tinggalnya. Kuala Mesuji adalah nama kampung tempat Jebat tinggal bersama ibunya.

Novel ini juga bercerita tentang bagaimana perjuangan masyarakat Kuala Mesuji menjalani kehidupan dan perjuangan anak-anak Kuala Mesuji untuk meraih pendidikan yang layak. Pendidikan di Kuala Mesuji dapat disebut jauh dari kata layak, tidak ada guru-guru yang mau mengajar di sana. Guru di sana berasal dari masyarakat itu sendiri, yang masih peduli dengan pendidikan anak-anaknya. Hal ini terjadi karena letaknya jauh dari perkotaan, bangunan dan fasilitas sekolah pun jauh dari kata layak.

Kuala Mesuji adalah perkampungan terapung yang ada di Kabupaten Mesuji, Lampung. Sebagian besar para penduduknya berprofesi menjadi nelayan. Untuk dapat sampai ke perkampungan Kuala Mesuji, dapat ditempuh dengan perahu melalui dermaga Rawa Jitu.

Berdasarkan latar belakang tersebut, tujuan penelitian ini adalah untuk mendeskripsikan kritik sosial dalam novel Maafkan Aku, Kuala Mesuji, dan mendeskripsikan bentuk penyampaian kritik sosial dalam novel Maafkan Aku, Kuala Mesuji.

Berdasarkan tujuan penelitian di atas, manfaat yang akan didapat dalam penelitian 
ini adalah mengetahui masalah-masalah sosial yang terdapat dalam novel Maafkan Aku, Kuala Mesuji Karya Fajar.

\section{Landasan Teori dan Metode Penelitian}

\subsection{Landasan Teori}

Suatu karya sastra tidak cukup dipahami jika hanya diteliti strukturnya saja tanpa kerja sama dengan disiplin ilmu lain. Hal ini karena masalah yang terkandung di dalam suatu karya sastra pada dasarnya merupakan masalah masyarakat. Jakob Sumardjo (1979: 12) mengungkapkan bahwa sastra adalah produk masyarakat. Ia berada di tengah masyarakat karena dibentuk oleh anggota-anggota masyarakat berdasarkan desakan-desakan emosional atau rasional dari masyarakatnya. Jadi, jelas bahwa kesusasteraan bisa dipelajari berdasarkan disiplin ilmu sosial juga, dalam hal ini sosiologi.

Sosiologi sastra merupakan kajian tentang segala sesuatu yang menyangkut masyarakat. Termasuk permasalahannya dan kaitannya dengan hajat hidup orang banyak. Hal ini sesuai dengan pernyataan Damono (1984: 6) sosiologi sastra adalah telaah objektif dan ilmiah tentang manusia di dalam masyarakat, telaah tentang lembaga, dan proses sosial. Sosiologi mencari tahu bagaimana masyarakat dimungkinkan, bagaimana masyarakat berlangsung, dan bagaimana ia tetap ada. Dengan mempelajari lembaga sosial dan segala masalah perekonomian, keagamaan, politik, dan lain-lain kesemuanya itu merupakan struktur sosial. Kita mendapatkan gambaran tentang cara-cara manusia menyesuaikan diri dengan lingkungannya, tentang mekanisme sosialisasi, dan proses pembudayaan yang menempatkan anggota masyarakat pada tempatnya masing-masing. Selanjutnya Sapardi Djoko Damono mengungkapkan dalam bukunya Sosiologi Sastra, Sebuah Pengantar Singkat:

1. Sosiologi komunikasi sastra, yaitu menempatkan kembali pengarang ke dalam konteks sosialnya (status, pekerjaan, keterkaitan akan sesuatu kelas tertentu, ideologi, dan sebagainya) lalu meneliti sejauh itu untuk mengetahui semua yang memengaruhi karyanya.

2. Penafsiran teks secara sosiologis, yaitu menganalisis gambaran tentang dunia dan masyarakat dalam karya sastra. Kemudian dikaji sejauh mana gambaran itu serasi dengan kenyataan (Damono, 1984: 129).

Berkaitan dengan pendekatan sosiologi sastra seringkali dikaitkan dengan situasi sosial tertentu, seperti sistem politik, ekonomi, hukum, dan sebagainya. Penelitian sosiologi dilakukan dengan menjabarkan pengaruh masyarakat terhadap sastra dan kedudukan sastra dalam masyarakat.

Dari uraian di atas dapat diperoleh gambaran bahwa sosiologi sastra merupakan pendekatan terhadap karya sastra dengan mempertimbangkan segi-segi kemasyarakatan, mempunyai lingkup yang luas, beragam, dan rumit yang menyangkut pengarang, karya, dan pembacanya.

Kritik sosial dalam karya sastra mempunyai kesempatan yang lebih luas bila dibandingkan seni lain di luar sastra. Kesempatan yang dimaksud berkaitan erat dengan fasilitas yang dimiliki sastra sebagai seni verbal. Darma (1995: 113) menyatakan bahwa karya sastra mempunyai kesempatan yang lebih luas bila dibandingkan dengan karya seni lainnya. Sastra mampu mengadakan hubungan langsung dengan pembaca. Selain itu, sastra memiliki fasilitas yang lebih luas untuk menggerakkan pathos pembaca, yaitu simpati dan merasa terlibat dalam peristiwa menthalyang terjadi dalam karya tersebut. Fasilitas tersebut berupa tokoh-tokoh, alur, dan setting yang terdapat dalam sastra (novel).

Menyampaikan kritik sosial bagi karya sastra bermakna sebagai cara sastra menyalurkan aspirasi masyarakat. Bagi sastra, menyampaikan kritik sosial adalah salah satu cara memosisikan sastra sebagai media pelepasan kegelisahan, keprihatinan, dan bahkan kemarahan masyarakat. Kritik sosial merupakan tanggapan pengarang terhadap fenomena permasalahan yang ada disekelilingnya, sehingga dapat dikatakan 
bahwa seorang pengarang tidak bisa lepas dari pengaruh sosial budaya masyarakatnya.

Menurut Nurgiyantoro (2009: 331), sastra mengandung pesan kritik akan lahir di tengah masyarakat jika terjadi hal-hal yang kurang beres dalam kehidupan sosial dan masyarakat. Kritik sosial dapat diartikan sebagai penilaian atau pertimbangan terhadap sesuatu mengenai masyarakat yang menyimpang dari tatanan yang seharusnya terjadi, seperti moral, norma, ekonomi, budaya, dan politis melalui karya sastra. Kritik sosial sebagai upaya untuk menentukan nilai hakiki masyarakat lewat pemahaman dan penafsiran realitas sosial, yaitu dengan memberi pujian, menyatakan kesalahan, dan mempertimbangkannya. Dalam hal ini, Sarwadi (1975: 4-6), menyatakan bahwa kritik sosial dalam sastra merupakan salah satu wujud pencerminan aktif terhadap situasi masyarakat. Timbulnya kritik dalam kesusasteraan Indonesia dikarenakan hal-hal berikut. Pertama, adanya pertentangan dan perbedaan yang mencolok dan kontras antara harapan dan kenyataan. Bentuk-bentuk pertentangan yang kontras itu meliputi; (a) tidak ada antara janji-janji dan dengan kenyataan yang terjadi; (b) tidak ada kesesuaian kata dan perbuatan; (c) tidak ada kesesuaian kedudukan seseorang dengan perbuatan; (d) tidak ada kesesuaian kepercayaan, pola pikir, adat istiadat, yang hidup di masyarakat dengan agama yang benar. Kedua, adanya pihak penguasa yang melakukan tindakan menekan atau menindas sehingga menimbulkan penderitaan.

\subsection{Metode Penelitian}

Metode yang dipakai dalam penelitian ini adalah deskriptif kualitatif, dengan tahap-tahap pelaksanaan, yaitu tahap penyediaan data, tahap analisis data, dan tahap penyajian hasil analisis data.

Sumber data dalam penelitian ini adalah novel Maafkan Aku, Kuala Mesuji karya Fajar yang diterbitkan Dandra Pustaka Indonesia, Yogyakarta 2016, dan buku-buku serta referensi lain yang terkait dengan penelitian. Penelitian ini difokuskan pada kritik sosial yang terdapat dalam novel Maafkan $A k u$, Kuala Mesuji karya Fajar.
Teknik analisis data yang digunakan dalam penelitian ini adalah deskriptif kualitatif karena data memerlukan penjelasan secara deskriptif

Tahap penyajian hasil analisis data dalam penelitian ini adalah mendeskripsikan hasil analisis data yang mengandung unsur-unsur kritik sosial yang terdapat dalam novel Maafkan Aku, Kuala Mesuji karya Fajar.

\section{Pembahasan}

Masalah sosial adalah gejala atau fenomena yang muncul dalam realitas kehidupan bermasyarakat. Dalam kehidupan sehari-hari fenomena tersebut hadir bersamaan dengan fenomena sosial yang lain. Oleh karena itu, untuk dapat memahami sebagai masalah sosial, dan membedakannya dengan fenomena lain dibutuhkan suatu identifikasi. Masalah sosial timbul karena individu gagal dalam proses sosialisasi atau karena cacat yang dimilikinya, dalam sikap dan perilaku tidak berpedoman pada nilai-nilai sosial dan nilainilai kepercayaan yang ada dalam masyarakat.

\subsection{Realitas Kehidupan dalam Novel Maafkan Aku, Kuala Mesuji}

Salah satu masalah sosial yang tak kunjung selesai di negeri ini salah satunya adalah masalah prostitusi. Prostitusi terus menjamur di negeri ini, salah satu faktor yang menyebabkan maraknya praktik prostitusi adalah faktor ekomomi. kebutuhan hidup yang terus meningkat, dan keterbatasan lahan pekerjaan menjadi, alasan untuk seseorang terjun ke dunia prostitusi. Dalam novel ini digambarkan seorang wanita tuna susila eks lokalisasi Gang Dolly, Surabaya yang mencoba peruntungannya di Mesuji. Lin adalah gambaran seorang yang memilih jalan pintas, demi untuk menghidupi keluarganya. Setelah lokalisasi Gang Dolly ditutup, Lin dan beberapa temannya pindah ke Mesuji, untuk melakukan perkerjaan yang sama.

" Ia bernama Lin, sang palacur murahan yang membuat isi bumi sangt muak, hingga bersumpah tak akan menerima jasadnya." (Fajar: 2) 
"Ibu majikan marah besar. Tak ada makan siang gratis di hampir semua belahan bumi termasuk di sini. Mana mungkin membiarkan Lin berkutat dengan masalahnya sedang ia dituntut berbagai kebutuhan." (Fajar: 9-10)

Pada kutipan tersebut menggambarkan bagaimana Mesuji menjadi salah satu pelarian bagi penghuni eks Dolly untuk melanjutkan profesinya sebagai wanita tunasusila. Hal ini menjadi salah satu contoh kegagalan pemerintah dalam menangani salah satu penyakit masyarakat. Penutupan lokalisasi Gang Dolly yang tidak didukung oleh terbukanya lapangan kerja yang memadai menjadikan beberapa para wanita tunasusila Gang Dolly, tetap menjadi wanita tunasusila dengan cara berpindah tempat.

Selain masalah prostitusi, masalah lainnya adalah taraf ekonomi sebagian masyarakat di Kuala Mesuji yang masih berada pada tingkat yang lemah di bawah. Hal ini terlihat dalam kutipan novel berikut ini.

"Di atas todongaan ujung senjata api rakitan, semua isi angkutan reot bergerak keluar dengan tubuh gemetar. Wajah mereka mulai pucat, jantung berdebar tanpa irama. Para penghadang mengacak-ngacak isi mobil dan merampas beberapa barang bawaan. Mereka juga menggeledah para penumpang satu persatu, dari ujung kaki hingga ujung kepala." (fajar: 23)

Kutipan novel di atas, menggambarkan bagaimana kriminalitas juga masih menjadi bagian di beberapa daerah di Indonesia, juga di Mesuji. Peredaran senjata rakitan di kalangan masyarakat menambah daftar panjang tingkat kriminalitas, yang harus secepatnya diberantas. Sebagaian besar masyarakat Kuala Mesuji bermata pencaharian sebagai nelayan. Profesi yang sangat mengandalkan ketersedian ikan di sungai, kondisinya menjadi lain ketika sungai itu tercemar karena limbah-limbah industri yang mengaliri sungai tersebut. hal ini terdapat dalam kutipan novel berikut ini.

"Setiap penghujung tahun, persisnya bulan 11 hingga 8 , aliran limbah akan merendam sepanjang Sungai Mesuji hingga semua makhluk di dalamnya keracunan. Ikan, udang juga kerang yang selamat akan berpindah ke tempat paling jauh di tengah laut lepas." (Fajar: 54)

Pada kutipan novel tersebut digambarkan bagaimana keadaan di aliran sungai Kuala Mesuji, pada waktu-waktu tertentu aliran sungai Kuala Mesuji dipenuhi oleh limbah industri, hal tersebut mengakibatkan ikan-ikan dan hewan-hewan lainnya yang ada di sungai Kuala Mesuji menjadi mati. Hal ini berdampak pada berkurangnya mata pencaharian masyarakat kampung Kuala Mesuji yang sebagian besar menjadi nelayan.

Pemekaran yang direncanakan tidak dengan matang, menjadi kendala dalam pembangunan suatu daerah. Di beberapa daerah terjadi ketimpangan kehidupan antara masyarakat perkotaan dan masyarakat pesedaan, juga dalam segi fasilitas. Dalam novel ini digambarkan kampung Kuala Mesujiyang terdapat di pinggiran Sungai Mesuji. Karena letaknya yang jauh dari kota, membuat fasilitas di sana sangatlah minim. Hal ini terlihat dalam kutipan novel berikut ini.

"Tak ada jalan darat bagi
perumahan terapung di Kuala
Mesuji. Kalau bukan dengan
perahu, jarak antara-rumah
dihubungkan oleh semacaam
jembatan berupa beberapa
batang kayu gelam dan bambu
pegangan." (Fajar: 66)

Pada kutipan novel di atas digambarkan bagaimana suasana perkampungan nelayan di Kuala Mesuji. Rumah-rumah yang berada di aliran sungai Kuala Mesuji, hanya terhubung dengan jembatan kayu yang dibuat secara 
swadaya masyarakat. Belum adanya jembatan yang permanen, menjadi kendala bagi para penduduk untuk melakukan ativitas sehari-hari mereka.

$\begin{array}{lrr}\text { "Bayangkanlahnasib desa-desa } \\ \text { perbatasan dengan } & \text { negara } \\ \text { tetangga yang tragis, } & \text { maka } \\ \text { begitulah kondisi } & \text { yang } \\ \text { menimpa Kuala } & \text { pada } \\ \text { akhirnya."(Fajar: 71) } & \end{array}$

Pada kutipan novel di atas, dapat tergambarkan bagaimana kondisi kampung Kuala Mesuji yang sangat minim fasilitas dan tidak diperhatikan oleh pemerintah.

Pemekaran wilayah, tidak selalu berdampak baik, setidaknya ini yang dirasakan oleh masyakarat Mesuji, yang dituangkan Fajar dalam novelnya. Hal ini terlihat dalam kutipan novel berikut ini.

"Kini Lin mulai tahu di mana ia berada. Kata 'Rawa Jitu' pernah didengarnya sebelum kejadian tragis itu. Adalah potret buram euforia pemekaran wilayah penyebab muara di bibir Selat Sunda ini menjadi bagian dari Kabupaten Tulang Bawang secara geografis. Kondisi yang memunculkan dilema sebab historis kampung Kualasindangyang lazim disebut Kuala Mesuji adalah bagian dari kampung Sungai Sindang Kabupaten Mesuji yang saat ini masih berdiri." (Fajar: 70-71)

Pada kutipan tersebut digambarkan bahwa pemekaran wilayah menjadi masalah baru yang dihadapi oleh masyarakat Mesuji. Sengketa wilayah menyebabkan tersendatnya pembangunan yang ada di Kuala Mesuji.

\subsection{Realitas Pendidikan di Kuala Mesuji}

Pendidikan merupakan hak semua warga negara Indonesia yang diatur oleh undangundang, pendidikan yang layak di setiap jenjangnya adalah tanjung jawab baik pemerintah pusat, maupun pemerintah daerah untuk dapat menciptakan pendidikan yang layak, dengan cara penyiapkan segala fasilitas pendidikan. Akan tetapi, pada kenyataannya masih banyak daerah-daerah yang jauh dari perkotaan tidak memiliki fasilitas pendidikan yang layak, salah satunya di Kuala Mesuji. Hal ini dapat dilihat pada kutipan novel berikut ini.

"Sejak berpuluh tahun SD itu adalah satu-satunya sekolah yang ada di dusun terapung ini, Nak. Didirikan dengan bergotong royong atas kemauan masyarakat. Cuma orang-orang yang mampu saya yang bisa sekolah lebih tinggi di luar, sebab biayanya juga tidak sedikit, pendidikan adalah harta termahal bagi anak-anak kuala." (Fajar: 53)

Pada kutipan novel di atas ini menggambarkan bagaimana pendidikan menjadi suatu yang mahal di Kuala Mesuji. Dalam kutipan tersebut menggambarkan hanya ada satu SD di perkampungan Kuala Mesuji. Sekolah yang didirikan dengan biaya masyarakat itu sendiri (swadaya) dan jauh dari kata layak.

Selain fasilitas yang menjadi tanggung jawab pemerintah dalam menciptakan pendidikan yang berkualitas, salah satu faktor lainnya adalah ketersediannya tenaga pendidik disetiap jenjangnya. Tidak dapat dipungkiri, saat ini masih banyak tenaga pendidik yang tidak mau ditempatkan di daerah-daerah terpencil, yang jauh dari perkotaan. Hal ini dapat dilihat pada kutipan novel berikut ini.

"Tak ada guru pegawai yang mau tinggal di sini. Kalaupunada, kami sendiri tak mampu menjanjikan hidup layak bagi mereka.” (Fajar: 53)

"Kami tak memiliki buku untuk dikoleksi, Lin. buku adalah barang mewah yang tak mudah mendapatkannya. lebih mahal dari sinar bulan. Kau tahu, di perpustakan ini anak-anak sudah mengganti fungsi buku dengan melepaskan pandangan 
pada hamparan sungai sambil

terpejam." (Fajar:76)

Fasilitas penunjang pendidikan seperti buku, menjadi barang mewah untuk dimiliki oleh anak-anak di Kampung Kuala Mesuji. Dalam kutipan novel berikut ini, memperlihatkan bagaimana kurangnya perhatian pemerintah terhadap pendidikan di daerah-daerah yang jauh dari pusat pemerintahan.

"Lin diberi sebuah pena murahan yang warna dan tintanya sama-sama biru. Juga sebuah buku besar absen siswa kelas 1 dan 6 , daftar nilai, dan beberapa catatan penting tantang hutang sekolah yang harus dibayar di toko fotokopi Pasar Rawa Jitu." (Fajar: 84)

Agar kegiatan belajar mengajar di SD Kampung Kuala Mesuji tetap berjalan, tidak jarang mereka berhutang untuk mendapatkan peralatan sekolah seperti kapur tulis. Dalam kutipan novel di atas digambarkan bagaimana kurangnya fasilitas pendidikan

Selain tidak ada sekolah yang layak, pendidikan di kampung Kuala Mesuji pun selalu dilanda masalah. Tidak ada guru yang mau menetap, dikarenakan karena lokasinya yang jauh dari perkotaan, selain itu karena dana operasionalnya sekolah tersebut bersumber dari swadaya masyakarat yang masih serba kekurangan.

" 'Oleh sebab itu, para orang tua di sini lebih memilih mendidik anak-anaknya menjadi nelayan dari pada berfikir tentang sekolah. Hanya itu satu-satunya cara menghadapi hidup. Sekolah adalah puncak bukit emas yang tidak mungkin bisa didaki hanya dengaan ayunan dayung. Kami tak mampu dan harus mendahulukan mencari makan.' " (Fajar: 55)
Pendidikan menjadi barang yang mewah di Kampung Kuala Mesuji, selain tidak adanya fasilitas pendidikan yang memadai, perekonomian meraka mejadi alasan lain para orang tua untuk tidak menyekolahkan anaknya. Para orang tua di sana lebih senang anak-anaknya untuk membantu mereka bekerja sebagai nelayan, bekerja untuk menyambung hidup yang harus terus berjalan, ketimbang bersekolah.

\section{Penutup}

\subsection{Simpulan}

Berdasarkan analisis yang telah dikemukakan sebelumnya dapat ditarik kesimpulan sebagai berikut.

Pertama, novel Maafkan Aku, Kuala Mesuji karya Fajar muncul sebagai refleksi terhadap pemekaran wilayah yang kurang berjalan dengan baik. Pada novel ini Fajar menyoroti realitas sosial yang ada di Mesuji sebagai satu dari beberapa banyak daerah yang terkena pemekaran wilayah. Pemekaran wilayah yang terkesan hanya bagi-bagi kekuasaan, dan tidak memikirkan pembangunan daerah tersebut. Realitas kehidupan sosial dan buramnya potret pendidikan menjadi imbas dari itu semua.

Kuala Mesuji yang merupakan gambaran tentang bagaimana masyarakat di dalamnya harus berjuang untuk hidup, berjuang untuk mendapatkan pendidikan yang layak, tempat tinggal yang layak coba diangkat oleh Fajar sebagai kritik tentang bagaimana kondisi di sebagian daerah di Indonesia.

Novel Maafkan Aku, Kuala Mesuji karya Fajar dengan kritik sosial. Novel ini mengemukakan kritik terhadap beberapa masalah yang aktual di Indonesia, bahkan hingga saat ini. Kritik sosial tersebut antara lain adalah kritik terhadap pendidikan dan kehidupan yang layak.

Kedua, kritik sosial Fajar dalam novel Maafkan Aku, Kuala Mesuji sangat bermanfaat bagi bangsa Indonesia untuk dapat menyembuhkan berbagai penyakitnya. Menulis karya sastra dengan bumbu kritik sosial bagi seorang sastrawan tidaklah sekadar melakukan kritik terhadap pihak lain. Pengarang pun, dengan caranya sendiri memberi alternatif 
solusi bagi permasalahan yang dibicarakannya. Karena itu, karya sastra dapat pula dianggap sebagai bentuk pencerahan masyarakat. Bentuk pencerahan ini biasanya sejalan dengan latar belakang pengarang dan ikut mewarnai karya sastra yang ditulisnya.

\subsection{Saran}

Berdasarakan manfaat penelitian yang diajukan maka saran-saran yang perlu disampaikan adalah sebagai berikut ini.

1. Hasil penelitian ini hendaknya dapat dijadikan salah satu acuan oleh pembaca untuk memahami kritik sosial dalam novel Maafkan Aku, Kuala Mesuji karya Fajar.Di samping itu, Pembaca juga hendaknya dapat memperoleh pengalaman dan wawasan tentang kritik sosial. Selain itu, kisah tentang perjuangan anak-anak Kuala Mesuji dalam mendapatkan pendidikan dan masyarakat Kuala Mesuji yang harus berjuang demi menyambung hidup.

2. Masih banyak alternatif penelitian yang dapat dilakukan terhadap novel Maafkan $A k u$, Kuala Mesuji karya Fajar dengan menggunakan pendekatan yang berbeda, misalnya pendekatan strukturalisme, semiotik, moral, resepsisastra, dan sebagainya. Dengan demikian, masih terbuka luas bagi peneliti selanjutnya untuk melakukan penelitian dalam novel Maafkan Aku, Kuala Mesuji karya Fajar dengan tindak lanjut penelitian ini.

\section{Daftar Pustaka}

Darma, Budi. 1995. Harmonium. Yogyakarta:

Pustaka Pelajar.

Damono, Sapardi Djoko. 1984Sosiologi Sastra: Sebuah Pengantar Ringkas. Jakarta Pusat: Pusat Pembinaan dan Pengembangan Bahasa.

Endraswara, Suwardi. 2004. Metodelogi Penelitian Sastra. Yogyakarta: Penerbit Pustaka Widyatama.

Fajar, 2016. Maafkan Aku, Kuala Mesuji. Diandra Pustaka Indonesia. Yogyakarta.

Luxemburg, Jan Van, dkk. 1989. Pengantar Ilmu Sastra. Jakarta: PT Gramedia Pustaka Utama.
Nurgiyantoro, Burhan. 2009. Teori Pengkajian Fiksi. Yogyakarta: Gajah Mada University Press

Kuntowijoyo. 1999. Budaya dan Masyarakat Yogyakarta: PT. Tiara Wacana Yogya.

Sumardjo, Jakob. 1979. Masyarakat dan Sastra Indonesia. Yogyakarta: Nur Cahaya.

Sarwadi. 1975. Sastra dalam Kesusasteraan Indonesia Modern. Yogyakarta: Tanpa Penerbit.

Soekanto, Soerjono. 2009. Sosiologi Suatu Pengantar. Jakarta: Rajawali Pers.

Teeuw, A. 1984. Sastra dan Ilmu Sastra. Jakarta : Pustaka Jaya.

Wellek, Rene dan Austin Warren. 1993. Teori Kesusastraan, Terjemahan Melani Budianta. Jakarta: Gramedia. 